\title{
Where We Came From: The Arcs of Judaism in America
}

\section{Deborah Dash Moore}

Director of the Frankel Center for Judaic Studies and a Frederick G.L. Huetwell Professor of History, University of Michigan

$\mathrm{F}$ or many years, histories of Jews and Judaism in America began in 1654 with the arrival in New Amsterdam of twenty-three refugees from the port city of Recife in Brazil. ${ }^{1}$ This starting point made sense as the beginning of a narrative for several reasons. First, it identified persecution of Jews as a prime motivation for coming to America. Jews left Recife when the city fell to the Portuguese. Portugal had forced Jews to convert in 1497. Fearing the Portuguese Inquisition, most of the one thousand Jews in Recife headed back to Amsterdam. A few, however, sailed up the coast and, through a series of misfortunes, landed in New Amsterdam instead. The notion that Jews came to the shores of North America due to persecution intensified the contrast between Old World and New. Second, in New Amsterdam Jews encountered the prejudices of Peter Stuyvesant, the colony's governor, who sought permission from his superiors in the Dutch West India Company to expel the ragged group of refugees. Stuyvesant did not succeed in his petition. His failure pointed to the promise that Jews would find a secure haven of refuge in North America as long as they took care of their needy. Third, this Jewish victory over Stuyvesant's prejudice also struck a blow for freedom of religion and toleration. Within several decades, the seaport housed an extraordinary array of religious groups. $^{2}$

Starting a history of American Judaism with 1654 in New Amsterdam held additional attractions because this Dutch seaport subsequently became New York City. By the twentieth century, New York became the largest Jewish city in the world. With two

\footnotetext{
${ }^{1}$ See the histories by Hasia R. Diner, The Jews of the United States, 1654-2000 (Berkeley: University of California Press, 2004), p. 3; Jonathan D. Sarna, American Judaism: A History (New Haven: Yale University Press, 2004), p. 1; and Beth S. Wenger, The Jewish Americans: Three Centuries of Jewish Voices in America (Garden City, NY: Doubleday, 2007), p. 1.

${ }^{2}$ Joyce D. Goodfriend, Before the Melting Pot: Society and Culture in Colonial New York City, 1664-1730 (Princeton: Princeton University Press, 1992); Frederick M. Binder and David M. Reimers, All the Nations Under Heaven: An Ethnic and Racial History of New York City (New York: Columbia University Press, 1995), pp. 1-32.
} 
million Jews, it was also the largest city in Jewish history. ${ }^{3}$ Furthermore, the twenty-three refugees included men, women, and children, thus foreshadowing future migrations of Jews to the United States. Jewish immigration, characterized as a family migration, involved more than young men and women seeking economic opportunity. Roughly a quarter of all Jewish immigrants were children, a fact that had economic implications as well as cultural ones. Perhaps most importantly it suggested that Jews intended to stay in the United States. Jewish rates of return migration hovered around 7\%, below average for immigrants during the $19^{\text {th }}$ and early $20^{\text {th }}$ centuries. ${ }^{4}$

These are all compelling reasons for starting the story of American Judaism in 1654, but recently some scholars have preferred to begin their account earlier, in 1492, when Columbus sailed from Spain on the voyage that would lead to his discovery of a new world, and at the identical historical moment when Jews were expelled from Spain, a catastrophic and traumatic event in Jewish history. ${ }^{5}$ A number of reasons make this new starting point compelling. First, it identifies Columbus's voyage of discovery with the expulsion of Jews, thus linking the opening of the New World with the closing of the Old World. Second, it strengthens connections of American Jews with European Jews and specifically with Sephardic Jews who hailed from Spain. Although the vast majority of American Jews trace their ancestors to Ashkenazi European Jews, that is, Jews identified with religious and cultural traditions formed in German and Polish lands; this earlier starting point integrates Sephardic Jews more firmly into the history of American Judaism. Third, it identifies a process of Jewish migration around the Atlantic world initiated in part by the Spanish expulsion and by Spanish exploration. This starting point explains how Jews came to be in Recife in the $17^{\text {th }}$ century.

Additional benefits accrue to 1492. Most importantly, it links the history of American Jews to broader changes sweeping the Jewish world in the $16^{\text {th }}$ and $17^{\text {th }}$ centuries and situates American Judaism as part of the Jewish Diaspora. Characterizing American Jewish culture as diasporic diminishes a tendency to see the situation of American Jews as exceptional, an inclination strengthened by trends within both American and Jewish historical writing. ${ }^{6}$ A 1492 starting date suggests that American Judaism should be seen as an expression of Judaism adapted to a historically unique situation.

\footnotetext{
${ }^{3}$ See Deborah Dash Moore, "Introduction," to City of Promises: A History of the Jews of New York in three volumes (New York: New York University Press, 2012).

${ }^{4}$ Paula E. Hyman, "Eastern European Immigrants in the United States," Jewish Women: A Comprehensive Encyclopedia, in Jewish Women's Archive, http://jwa.org/encyclopedia/article/eastern-europeanimmigrants-in-united-states.

${ }^{5}$ See Norman H. Finkelstein, American Jewish History: A JPS Guide (Philadelphia: The Jewish Publication Society of America, 2007), p. 13. Howard B. Rock, Haven of Liberty: New York Jews in the New World, 1654-1865 (New York: New York University Press, 2012). Page 5 begins the narrative with 1492, but the Introduction, p.1, with 1654.

${ }^{6}$ Tony Michels, "Is America 'Different'?: A Critique of American Exceptionalism," American Jewish History 96:3 (September 2012), pp. 201-224.
} 
These are just starting points for narratives of the American Jewish past that seek to explain where Jews came from. However, historical beginnings often imply a perspective on American Jews that assumes a connection between past and present. A look at two of the most popular contexts offered for understanding the arc of Judaism in America reveals the influence of historical perspectives. One interpretation situates American Judaism within the history of religion in America; another presents American Judaism within Jewish history.

Viewed within the framework of American religious history, Judaism appears as a distinctly urban religion. Judaism first took root in the colonial era in a handful of port cities with sufficiently negligible numbers of Jews to be statistically irrelevant. However, these Jews introduced non-Christian religious diversity into the urban culture of New York, Newport, Philadelphia, Charleston, and Savannah. As a result of Jewish petitions for civic rights and opportunities to practice Judaism, religious toleration gradually evolved into religious freedom and religious freedom often produced respect. In this fashion Jews and Judaism became part of the fabric of colonial America. They joined with other patriots in opposing the British. When George Washington assumed the presidency, he hailed Jews and Judaism in several eloquent letters to Jewish congregations. ${ }^{7}$ The United States, Washington wrote, "gives to bigotry no sanction, to persecution no assistance." 8

Democratic republicanism disrupted this colonial synthesis by empowering young Jews to experiment with new forms of religious expression. Reform Judaism emerged in Charleston in 1824 as a result. Then the arrival of hundreds, thousands, tens of thousands and finally hundreds of thousands of Jewish immigrants from Europe dramatically changed Judaism. They initially settled in cities throughout the United States and then, increasingly, concentrated in a handful of the nation's largest cities, especially New York (forty percent of all American Jews lived in New York City in 1940), but also Chicago and Philadelphia. ${ }^{\text {? }}$

The growth of Judaism in the United States followed some established American patterns. Congregationalism and lay leadership took root (the first rabbis only immigrated in the 1840s). Voluntarism stimulated community growth as men and women organized to provide for themselves and their children. Jews embraced public education, relegating Jewish education largely to supplementary forms. ${ }^{10}$ Gradually rabbis

\footnotetext{
${ }^{7}$ For a good overview of early American Jewish history see Eli Faber, A Time for Planting: The First Migration 1654-1820 (Baltimore: Johns Hopkins University Press, 1992).

8 "From the Newport Congregation to the President of the United States, August 17, 1790," in $A$ Documentary History of the Jews in the United States 1654-1875, ed. Morris U. Schappes (New York: Schocken Press, 1971), pp. 79-81.

${ }^{9}$ For a full discussion of this approach see Deborah Dash Moore, Urban Origins of American Judaism, George H. Shriver Lecture Series in Religion in American History (Athens, GA: University of Georgia Press, forthcoming 2014).

${ }^{10}$ Stephan F. Brumberg, Going to America, Going to School: The Jewish Immigrant Public School Encounter in Turn-of-the-Century New York (New York: Praeger, 1986).
} 
established elite modes of Judaism along with institutions to train rabbis and educators. Influenced by American Protestant denominationalism, Judaism eventually split into three large streams - Orthodox, Conservative, Reform. In the twentieth century the United States' open marketplace of religions coupled with separation of church and state nurtured new American forms of Judaism - Reconstructionism, Humanistic Judaism, Renewal Judaism. ${ }^{11}$

By the 1950s Judaism achieved public recognition as one of three constituent democratic religions of America: Protestantism, Catholicism, Judaism. This acceptance encouraged Jews to mount successful legal efforts to remove religion from public places, especially public schools, to create a religiously neutral public sphere. However, even as these campaigns were succeeding in the 1970s, a more fundamentalist Judaism associated with Lubavitch Hasidism challenged them. These pious Jews argued for greater visibility of Jewish symbols in public spaces (such as Hanukkah menorahs) as well as public support of parochial education. ${ }^{12}$

That is one arc: from small religious roots to a multi-branched tree. Jewish history offers a different arc.

Beginning in the colonial world, Jews established small, voluntary, synagogue communities throughout the Atlantic world connected via trade and family ties with such European port cities as Amsterdam and London. Unlike in Europe, however, colonial Jewish communities lacked corporate legal status; each was unique. All aspects of Jewish life regulated by Jewish communal authorities now were unregulated, including kosher food, circumcision, marriage, burial, education, holiday observance, and aid to indigent Jews and widows. Congregations attempted to govern Jews, but they achieved only moderate success. ${ }^{13}$

In the $19^{\text {th }}$ century Jews immigrated to the United States, transferring many elements of European Jewish culture. However, the basic American premise of a voluntary community and absence of any legal authority to enforce behaviors among Jews transformed efforts to transplant Jewish religious traditions. Left to their own devices, American Jews pioneered diverse forms of Judaism and Jewish community. For example, they created the first Jewish fraternal society (B'nai B'rith) and the first Jewish Young Men's Hebrew Association (YMHA). They introduced the first Jewish Sunday School with female teachers and the first Jewish orphan asylum. American Jews developed Jewish Community Centers (JCC's) as well as synagogue centers that housed together worship, recreation and education. They built hospitals and old age homes,

\footnotetext{
${ }^{11}$ Marc Lee Raphael, The Synagogue in America: A Short History (New York: New York University Press, 2011), pp. 44-168.

${ }^{12}$ Deborah Dash Moore, "Religious Pluralism in American Judaism," in Gods in America: Religious Pluralism in the United States, ed. Charles L. Cohen and Ronald L. Numbers (New York: Oxford University Press, 2013), pp. 146-57.

${ }^{13}$ Eli Faber, "America's Earliest Jewish Settlers, 1654-1820," The Columbia History of Jews and Judaism in America, ed. Marc Lee Raphael (New York: Columbia University Press, 2008), pp. 21-46.
} 
libraries and organizations to defend Jews from anti-Semitism. They also organized politically, forming labor unions, socialist fraternal societies, and Zionist groups. American Jews learned how to fundraise (needed if there were no taxes to support the Jewish community) and trained a group of Jewish communal professionals (social workers, educators, fund-raisers). In short, they cultivated an array of voluntary religious, educational, charitable, health and welfare organizations. ${ }^{14}$

Especially in the $20^{\text {th }}$ century American Jews increasingly focused on issues of individual and collective rights. They also sought to protect Jewish rights throughout the world. Efforts to mobilize other Americans to join their cause proved only partially successful. In the 1970s many American Jews, inspired by the Civil Rights and feminist movements, embraced the democratic concept of equality. This triggered furious debates among the different Jewish religious streams over whether women should have equal rights within Judaism. Without a consensus on women's position within Judaism, American Jews remained divided, making diversity along with innovation a hallmark of American Judaism. ${ }^{15}$

Despite significant accomplishments, American Judaism fell short. Measured against the two most profoundly important events for Jews in the twentieth century - the European Holocaust of six million murdered Jews and the establishment of the State of Israel - American Jews did not affect the course of Jewish history. Historians accused them of failing to rescue European Jews from the Holocaust and scholars of Israeli history regularly ignored American Jewish contributions to the establishment of the Jewish state during the postwar years. ${ }^{16}$ Indeed, despite their numbers, wealth, political acumen, and religious creativity, American Jews were often perceived as standing on the sidelines of Jewish history. In addition to these alleged failures and despite American Jews' creativity in producing new forms of religious life, many Jewish scholars saw Jewish social and economic integration into American society, a product of the 1970s, as

\footnotetext{
${ }^{14}$ In addition to Sarna and Diner's overviews, see Dianne Ashton, "Expanding Jewish Life in America, 1826-1901," for the nineteenth century; and Eric L. Goldstein, "The Great Wave: Eastern European Jewish Immigration to the United States, 1880-1924," in The Columbia History of Jews and Judaism in America, ed. Marc Lee Raphael (New York: Columbia University Press, 2008), pp. 47-69 and 70-92 respectively.

${ }^{15}$ Pamela Nadell, "A Bright New Constellation: Feminism and American Judaism," in The Columbia History of Jews and Judaism in America, ed. Marc Lee Raphael (New York: Columbia University Press, 2008), pp. 385-405.

${ }^{16}$ The scholarship attacking American Jews is extensive. For example see David S. Wyman and Rafael Medoff, A Race Against Death: Peter Bergson, America and the Holocaust (New York: New Press, 2002) and Haskel Lookstein, Were We Our Brothers Keepers? The Public Responses of American Jews to the Holocaust, 1938-1944 (New York: Hartmore House, 1985). For a study that integrates the American Jewish experience into a history of Israel see Allon Gal, David Ben Gurion and the American Alignment for a Jewish State (Bloomington: Indiana University Press, 1991) and Anita Shapira, "A Comparative Study of Zionist Leadership: Abba Hillel Silver and David Ben-Gurion," in Abba Hillel Silver and American Zionism, ed. Mark A. Raider and Jonathan D. Sarna (New York: Frank Cass, 1997), pp. 33-44.
} 
a threat to Jewish continuity. The increasing popularity of intermarriage diluted Jewish communal cohesion and weakened American Judaism. ${ }^{17}$

This is a second arc: from an offshoot to a mature and somewhat ornamental branch. American Judaism in this account is a pleasant detour from the main path of Jewish history.

Jews discovered in the United States an unprecedented situation. Despite centuries living as a minority, they never had enjoyed such opportunities of freedom of religious expression within a society grounded in individualism as existed in America. Ironically, encounters with prejudice and discrimination proved far more familiar to Jews along with feelings of vulnerability and insecurity. Those elements of anti-Semitism connected Jews to their long history. New in America were confidence, acceptance, and a spiritual eclecticism. Jews often found an unanticipated welcome in religious milieus of democratic diversity and pluralism that challenged them repeatedly to reimagine where Judaism belonged.

\footnotetext{
${ }^{17}$ Deborah Dash Moore, "Religious Pluralism in American Judaism," pp. 157-60. 